\title{
Outcome measurements following palatal soft tissue graft harvesting: A review
}

\author{
Violeta Malpartida-Carrillo ${ }^{1}$, Pedro-Luis Tinedo-Lopez ${ }^{1}$, Maria-Eugenia Guerrero ${ }^{2}$, José-Luis Huamani-Echaccaya ${ }^{3}$, \\ Mutlu Özcan ${ }^{4}$, Cassiano-Kuchenbecker Rösing ${ }^{5}$
}

\author{
${ }^{1}$ DDS, MSc. Professor, School of Stomatology, Universidad Privada San Juan Bautista, Lima, Perú \\ ${ }^{2}$ DDS, PhD. Professor, Department of Medico Surgical Stomatology, Faculty of Dentistry, Universidad Nacional Mayor de San \\ Marcos, Lima, Perú \\ ${ }^{3}$ DDS, MSc. Professor, School of Stomatology, Universidad Privada San Juan Bautista, Ica, Perú \\ ${ }^{4}$ DDS, PhD. Professor, Center of Dental Medicine, Division of Dental Biomaterials, Clinic for Reconstructive Dentistry, Univer- \\ sity of Zurich, Zurich, Switzerland \\ ${ }^{5}$ DDS, PhD. Professor, Department of Periodontology, School of Dentistry, Federal University of Rio Grande do Sul, Porto Alegre, \\ Brazil
}

Correspondence:

School of Stomatology

Universidad Privada San Juan Bautista

302-304 Jose Antonio Lavalle Avenue

Chorrillos, Lima-Perú

viletayu_30@hotmail.com

\begin{abstract}
Malpartida-Carrillo V, Tinedo-Lopez PL, Guerrero ME, Huamani-Echaccaya JL, Özcan M, Rösing CK. Outcome measurements following palatal soft tissue graft harvesting: A review. J Clin Exp Dent. 2021;13(5):e527-35.
\end{abstract}

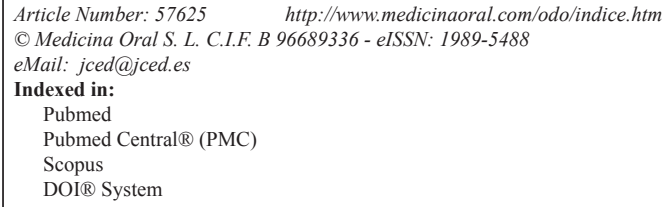

\begin{abstract}
Background: Free gingival graft (FGG) and connective tissue graft (CTG) are two of the most commonly techniques performed in periodontal and peri-implant plastic surgery. Although several outcome measurements have been proposed for evaluation of palatal wound healing and patient morbidity, a comprehensive review about these variables is lacking. The objective of this review is to present comprehensive information about outcome measurements related to postoperative palatal wound healing and postoperative patient-reported morbidity after FGG or CTG procedures. Material and Methods: An electronic search of English language dental literature in the Medline database via PubMed access was conducted from May 1994 to May 2020 following the PRISMA guidelines. Electronic search strategy complemented by hand search of impacting related dental journals, and the reference list of all included studies were used to complete data collection considering only clinical trials. Finally, inclusion criteria were applied to identify articles after full-text evaluation.

Results: A total of 111 articles were identified. After the exclusion of 34 articles based on title and abstract evaluation, 77 articles were full text screened. Following, 46 articles were excluded since they evaluated other surgical areas. Finally, 31 studies were selected and included for final evaluation. Outcome measurements were classified in variables collected by indexes and systems assessed professionally and patient-centered measurements. Visually-assessed measurements include indexes, photographs, bleeding and use of laboratory-aided measurements. Patients-centered outcomes comprise pain, discomfort and quality-of life, among others.

Conclusions: The most commonly used outcome measurements related to postoperative palatal wound healing are hydrogen peroxide test, tissue color match, visual inspection, and bleeding evaluation. Pain perception, analgesic consumption, discomfort sensation, burning sensation, and changes in feeling habits are the most commonly used outcome measurements related to postoperative patient-reported morbidity.
\end{abstract}

Key words: Morbidity, patient comfort, periodontics, tissue harvesting, wound healing. 


\section{Introduction}

Esthetic driven-dentistry has become an integral part in periodontal and peri-implant treatment. Several soft tissue grafting techniques such as free gingival graft (FGG), connective tissue graft (CTG), grafts combining these two modalities, and pedicle grafts have been used for re-establishing the keratinized tissue width (KTW), augmenting tissue thickness, correcting mucogingival deformities, and improving esthetics, at teeth and dental implant sites $(1,2)$.

Despite the introduction of the above aforementioned techniques, the FGG and the CTG are two of the most commonly performed techniques in periodontal and peri-implant plastic surgery that use a safety zone of the hard palate as a common site for harvesting soft tissue grafts (3). These procedures have gained popularity due to the reasonably straightforward surgical procedure and exceptionally predictable approach with reliable results (4). However, the main drawback of the FGG and the CTG procedures is patient morbidity at the palatal donor site that heals with primary or secondary intention approximately 2-4 weeks after the surgery (5), and requires a longer healing period with more patient discomfort and pain (6).

According to the literature, the current understanding about palatal wound healing is geared toward the study of periodontal dressing varieties to accelerate the healing process and to reduce prolonged pain and bleeding. Therefore, several materials such as hemostatic agents (absorbable gelatin sponge, absorbable collagen dressing, oxidized regenerated cellulose) (7-9), growth factors (10), and medical plant extracts (6), have been used to investigate their benefits on the palatal donor site. On the other hand, several methods for outcome evaluation such as modified Early-Wound Healing Index (11); visual inspection of color, contour, and texture changes (10); records of sensibility disorders, loss of sensor, changes in feeding habits, and pain perception (12) have been considered to evaluate healing characteristics and patient discomfort after FGG or CTG procedures. In addition, numerical and verbal rating scales have been included in postoperative questionnaires handed to patients $(6,9-11)$. However, to the best of the authors' knowledge, no studies have reported these methods in an organized manner and this would be an important tool for clinicians that perform periodontal and peri-implant plastic surgeries in order to adequately control the postoperative morbidity of the patients who undergo FGG or CTG procedures.

Hence, the aim of this review is to analyze and present comprehensive information about the outcome measurements evaluation related to postoperative palatal wound healing and postoperative patient-reported morbidity after undergoing FGG or CTG.

\section{Material and Methods}

The Medline database via PubMed access was comprehensively searched from May 1994 to May 2020 according to the Preferred Reporting Items for Systematic Review and Meta-Analysis (PRISMA) guidelines (13). The search strategy was carried out using the following terms: "palatal", "gingival graft" and "patient outcomes". These terms were combined with the Boolean operators "AND" and "OR". The final strategy was: ((palatal) AND ((free gingival graft) OR (connective gingival graft))) AND (patient outcomes). In addition, a hand search in dental journals (Journal of Periodontology, Journal of Clinical Periodontology, Clinical Oral Implants Research, International Journal of Oral and Maxillofacial Implants, Clinical Implant Dentistry and Related Research, International Journal of Periodontics and Restorative Dentistry) was also performed and the reference lists of all included articles were manually cross-referenced to complete data collection. Two reviewers (VMC and PLTL) screened the titles and abstracts for eligibility. The two reviewers were able to reach a consensus for all articles accepted for inclusion. The inclusion criteria for selecting articles were clinical trials published in English that included outcome measurements evaluated after FGG or CTG harvesting from the palatal donor site related to the wound healing and the patient morbidity after the procedures. Animal studies, in vitro studies, observational studies, case reports, case series, reviews, and narrative studies were not considered.

\section{Results}

A total of 88 articles were identified after the initial search in PubMed database and 12 articles by hand searching. From these, 10 articles were discarded due to duplicity. Twenty-one articles were added from the reference list of articles selected during initial search and 111 articles were screened based on title and abstracts. However, 34 publications were excluded after title and abstracts evaluation, leaving 77 articles whose full text were screened. Then, 46 articles were excluded based on the inclusion criteria because different surgical areas for healing outcome were evaluated (recipient sites). Finally, 31 studies were selected and included for final evaluation. Figure 1 shows the flowchart of the review to retrieve the included studies.

Among the methods for outcome measurements evaluation related to postoperative palatal wound healing (Table 1, 1 cont.), the organized articles were distributed considering different objective measurements such as index and scales, wound epithelialization test, wound visual clinical healing, wound photographic healing, bleeding evaluation, cytological analysis, laboratory analysis, and histological examination. Fick et al. (11) 


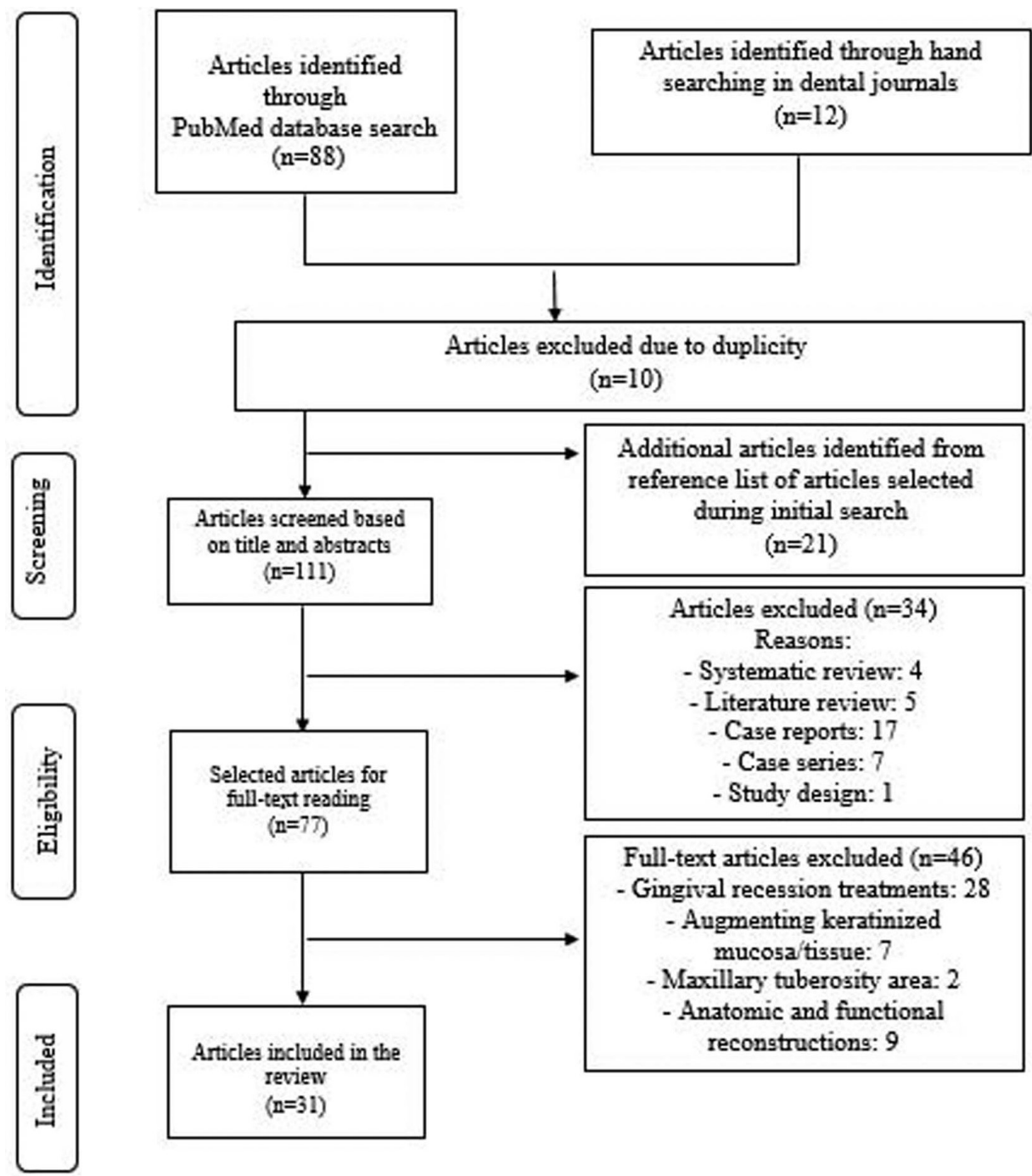

Fig. 1: Flowchart of the review to identify included studies.

Table 1: Description of outcome definitions and measures related to postoperative palatal wound healing retrieved in the literature.

\begin{tabular}{|c|c|c|c|}
\hline Outcome & Measures & Gingival graft & Parameters \\
\hline \multicolumn{4}{|l|}{ Index } \\
\hline $\begin{array}{l}\text { Modified Early-Wound } \\
\text { Healing Index (EHI) } \\
(11,14,15)\end{array}$ & $\begin{array}{l}\text { 1. Complete flap closure without fibrin line at } \\
\text { the palate. 2. Complete flap closure with fibrin } \\
\text { line at the palate. } 3 \text {. Complete flap closure with } \\
\text { small fibrin clot (s) at the palate. } 4 \text {. Incomplete } \\
\text { flap closure with partial necrosis of the palatal } \\
\text { tissue. 5. Incomplete flap closure with complete } \\
\text { necrosis of the palatal tissue (more than } 50 \% \text { of } \\
\text { the former flap is involved) }\end{array}$ & CTG & $\begin{array}{l}\text {-1-3: Primary wound closure; } \\
\text { 4-5: Secondary wound closure } \\
(11,14,15)\end{array}$ \\
\hline $\begin{array}{l}\text { Modified Landry-Wound } \\
\text { Healing Index (WHI) } \\
(14,17,18)\end{array}$ & $\begin{array}{l}\text { - Tissue color, response to palpation, } \\
\text { incision margins suppuration }(14,18) \\
\text { - Redness, presence of bleeding, granulation } \\
\text { tissue, epithelialization, suppuration (17) }\end{array}$ & FGG & $\begin{array}{l}\text {-1: Very poor or bad healing; } \\
\text { 5: Excellent healing }(17,18)\end{array}$ \\
\hline $\begin{array}{l}\text { Modified Manchester Scale } \\
\text { for Clinical Scar (17) }\end{array}$ & $\begin{array}{l}\text { - Color comparison with adjacent mucosa } \\
\text { - Contour comparison with adjacent mucosa } \\
\text { - Distortion comparison with adjacent mucosa }\end{array}$ & FGG & $\begin{array}{l}\text { - Color. 0: Perfect match; 1: Slight } \\
\text { mismatch; 2: Obvious mismatch (17) } \\
\text { - Contour. 0: Similar; 1: Slightly proud } \\
\text { or indented; 2: Hypertrophic (17) } \\
\text { - Distortion. 0: No distortion; 1: Slight } \\
\text { distortion; 2: Obvious distortion (17) }\end{array}$ \\
\hline
\end{tabular}


Table 1 cont.: Description of outcome definitions and measures related to postoperative palatal wound healing retrieved in the literature.

\begin{tabular}{|c|c|c|c|}
\hline \multirow{2}{*}{$\begin{array}{l}\text { Wound epithelialization } \\
\text { test }\end{array}$} & \multirow[b]{2}{*}{$\begin{array}{l}3 \% \mathrm{H}_{2} \mathrm{O}_{2} \text { is sprinkled on the wound using } \\
\text { syringe/microbrush. If the epithelium is dis- } \\
\text { continuous, it diffuses into the connective } \\
\text { tissue, and the enzyme catalase acts on } \mathrm{H}_{2} \mathrm{O}_{2} \text { to } \\
\text { release water and oxygen showing bubbles on } \\
\text { the wound }\end{array}$} & \multirow[b]{2}{*}{ FGG } & \multirow[b]{2}{*}{$\begin{array}{l}\text { - None, partial, total (6) } \\
\text { - Yes, no }(8,12,19,25) \\
\text { - Complete, incomplete }(7,14,18,20 \text { - } \\
22,24) \\
\quad 1 / 3,2 / 3 \text { of the wound }(23)\end{array}$} \\
\hline & & & \\
\hline Toluidine blue test (7) & $\begin{array}{l}\text { Toluidine blue dye adheres to non-epithelial } \\
\text { tissues and imparts blue color to them }\end{array}$ & FGG & - Complete, incomplete (7) \\
\hline \multicolumn{4}{|l|}{$\begin{array}{l}\text { Wound visual clinical } \\
\text { healing }\end{array}$} \\
\hline $\begin{array}{l}\text { Tissue color match } \\
(6,14,15,18,20,26)\end{array}$ & $\begin{array}{l}\text { Visual Analog Scale (VAS 0-10 cm) for com- } \\
\text { parison with adjacent and opposite mucosa }\end{array}$ & FGG/CTG & $\begin{array}{l}\text { - 0: No color matching; } 10 \text { : Excel- } \\
\text { lent, perfect or very good matching } \\
(6,14,15,18,20,26)\end{array}$ \\
\hline Consistency $(18,26)$ & Palpation with a blunt instrument & FGG & - Soft, firm $(18,26)$ \\
\hline Swelling (14) & $\begin{array}{l}\text { Elevation of the tissues as a result of inflam- } \\
\text { mation }\end{array}$ & FGG/CTG & $\begin{array}{c}\text { - 0: Absent; 1: Slight; 2: Moderate; 3: } \\
\text { Severe (14) }\end{array}$ \\
\hline $\begin{array}{l}\text { Wound clinical healing } \\
\text { area }\left(\mathrm{mm}^{2}\right)(7,27)\end{array}$ & $\begin{array}{l}\text { Wound closure measurement area using a } \\
\text { periodontal probe }(7,27) \text { or a tracing grid }(7) \\
\text { for depth and size measures }\end{array}$ & FGG/CTG & - Width $x$ length $(7,27)$ \\
\hline $\begin{array}{l}\text { Wound clinical healing } \\
\text { percentage (9) }\end{array}$ & $\begin{array}{c}\text { Wound closure percentage using width, length, } \\
\text { and area dimensions }\end{array}$ & FGG & $\begin{array}{l}\text { - Formula: } \\
100 \times \text { (baseline dimension - postopera- } \\
\text { tive dimension) / baseline dimension (9) }\end{array}$ \\
\hline \multicolumn{4}{|l|}{$\begin{array}{l}\text { Wound photographic } \\
\text { healing }\end{array}$} \\
\hline $\begin{array}{l}\text { Visual inspection }(10,21,27- \\
30)\end{array}$ & $\begin{array}{l}\text { - Color, contour, texture (10) } \\
\text { - Shade, texture and morphology (21) } \\
\text { - Color match (27), VAS 0-10 cm (29) } \\
\text { - Wound epithelialization (28) } \\
\text { - Scar tissue (30) }\end{array}$ & FGG/CTG & $\begin{array}{l}\text { - 0: No color matching; } 1 \text { : Partial color } \\
\text { matching; } 2 \text { : Complete color match- } \\
\text { ing (27) } \\
\text { - None, partial, complete (28) } \\
\text { - 0: No color matching; 10: Ex- } \\
\text { cellent color matching (29) } \\
\text { - Presence, absence (30) }\end{array}$ \\
\hline $\begin{array}{l}\text { Wound healing area }\left(\mathrm{mm}^{2}\right) \\
(8,9,17,24,30)\end{array}$ & $\begin{array}{c}\text { Wound closure area or remaining palatal } \\
\text { wound area using image analyses programs. } \\
\text { Incomplete epithelialization measurement } \\
\text { considering the number of pixels }\end{array}$ & FGG/CTG & $\begin{array}{c}\text { - Formula: } \\
100 \mathrm{x} \text { postoperative healing area / } \\
\text { baseline wound area }(8) \\
\text { - Formula: } \\
\text { Total wound area }\left(\mathrm{mm}^{2}\right) \text { - [Total } \\
\text { wound area }(\mathrm{mm} 2) \times \text { the percentage } \\
\text { of wound epithelialization }(\%)](24) \\
\text { - Comparison of areas using brightness } \\
\text { parameters, the red-green chroma scale } \\
\text { and the yellow-blue chroma scale }(30)\end{array}$ \\
\hline \multicolumn{4}{|l|}{ Other outcomes } \\
\hline $\begin{array}{l}\text { Bleeding evaluation } \\
(7,14,15,19,24,27,28)\end{array}$ & $\begin{array}{l}\text { - Immediate bleeding: Bleeding after ap- } \\
\text { plication of external pressure }(7,14,24,27,28) \\
\text { - Delayed bleeding: Prolonged hemor- } \\
\text { rhage during the postsurgical period } \\
(7,14,15,19,24,27,28)\end{array}$ & FGG/CTG & $\begin{array}{c}\text { - Presence, absence }(7,14,15,19,24,28) \\
\text { - Positive, negative }(27)\end{array}$ \\
\hline Cytological analysis $(32,33)$ & $\begin{array}{l}\text { Epithelial keratinization, regeneration and } \\
\text { degradation evaluation }\end{array}$ & FGG & $\begin{array}{l}\text { - Keratinization index and superficial } \\
\text { cell index }(32,33)\end{array}$ \\
\hline Laboratory analysis (34) & Wound fluid sampling for ELISA analysis & FGG & - TGF- $\beta 1$, PDGF-BB, IL-8 (34) \\
\hline $\begin{array}{l}\text { Histological examination } \\
\text { (26) }\end{array}$ & $\begin{array}{l}\text { - Hematoxylin and Eosin (HE) staining: } \\
\text { For epithelial and connective tissues study } \\
\text { - Masson's Trichrome (MT) staining: For } \\
\text { mature collagen study }\end{array}$ & FGG & $\begin{array}{c}\text { - Hematoxylin and Eosin (HE) stain- } \\
\text { ing, Masson's Trichrome (MT) stain- } \\
\text { ing (26) }\end{array}$ \\
\hline
\end{tabular}

CTG: Connective Tissue Graft. FGG: Free Gingival Graft. ELISA: Enzyme-linked immunosorbent assays. TGF- $\beta 1$ : Transforming Growth Factor- $\beta 1$. PDGF-BB: Platelet-Derived Growth Factor-BB. IL-8: Interleukin-8. 
Isler et al. (14) and Alpan et al. (15) described the use of the modified Early-Wound Healing Index (EHI) for postoperative healing evaluation after CTG considering five different degrees related to primary and secondary wound closure. This index comes from the original EHI proposed by Wachtel et al. (16) for periodontal intrabony defects postoperative healing evaluation. Another index is the modified Landry Wound Healing Index (WHI) reported by Isler et al. (14) Samani et al. (17) and Ustaoglu et al. (18) for postoperative healing evaluation after FGG considering parameters from very poor to excellent healing. Moreover, Samani et al. (17) reported the modified Manchester Scale for Clinical Scar, specifically performed after FGG procedures.

Several studies provided information regarding the wound epithelialization evaluation using the hydrogen peroxide test (H2O2) $(6-8,12,14,18-25)$ and the toluidine blue test (7) after FGG procedures. The wound visual clinical healing may be evaluated considering the tissue color match by using the Visual Analogue Scale (VAS-10 $\mathrm{cm})$ for FGG and CTG procedures $(6,14,15,18,20,26)$. In addition, consistency $(18,26)$, and swelling $(14)$, have been also reported as wound healing parameters for FGG or CTG. On the other hand, Pandit et al. (27) reported the wound closure measurement area $(\mathrm{mm} 2)$ using a periodontal probe, whereas Sharma et al. (7) used a tracing grid (D-stent) for depth and size (width and length) measures after FGG or CTG procedures. Recently, Sousa et al. (9) analyzed the wound closure percentage after harvesting FGG using a recommended formula considering baseline and postoperative dimensions. The wound photographic healing can be evaluated through visual inspection of clinical photographies $(10,21,27-$ 30 ), considering characteristics of color, contour, and texture (10); shade, texture, and morphology (21); color match $(27,29)$; wound epithelialization (28); or scar tissue (30). Likewise, several authors reported the wound healing area $(\mathrm{mm} 2)$ or the remaining palatal wound area measured on clinical photographs using image analysis programs after FGG or CTG procedures $(8,9,17,24,30)$. Recently, Patarapongsanti et al. (8) and Isler et al. (24) recommended calculation formulas.

Another outcome measurement evaluation reported for FGG or CTG procedures is the bleeding evaluation $(7,14,15,19,24,27,28)$. This condition is evaluated as immediate bleeding (bleeding after application of external pressure) and delayed bleeding (prolonged hemorrhage during the postsurgical period). Finally, methods related to cytological analysis $(32,33)$, laboratory analysis $(34)$, and histological examination (26) have been considered as outcome measurements after FGG procedure.

Among the methods for outcome measurements evaluation related to postoperative patient-reported morbidity (Table 2), the organized articles were distributed considering pain perception, analgesic consumption, dis- comfort sensation, burning sensation, changes in feeling habits, sensibility disorders, stress, quality of life, and additional questions asked to the patients using questionnaires. Pain perception is one of the most reported methods used for FGG or CTG procedures evaluation. The patient informs his/her perception using the VAS-10 cm $(6,8-12,14,15,17,18,20,21,24-27,29,30,35-$ 37), five-point Verbal Rating Scale (VRS-5) (7,27), 101-point Numerical Rating Scale (NRS-101) (10), and three-point Verbal Descriptor Scale (VDS-3) (28). The number of analgesic consumptions is informed considering hours, days or weeks $(6,14,19-21,24,25,31,36,38)$. Reportedly, the discomfort sensation may also be informed using the VAS-10 $\mathrm{cm}(9,14,19,24,31,38)$, or the four-point Verbal Rating Scale (VRS-4) (10), whereas the burning sensation generally is informed using the VAS-10 $\mathrm{cm}(14,18,20,24,26,29)$. The changes or variations in feeling habits means changes in quality (liquid, soft or hard), and temperature of the food (cold, tepid or warm) $(12,28)$, or inability to chew $(31)$, and the VAS-10 cm is generally used $(14,19,24)$. Kecelli et al. (6), Ozcan et al. (12), Femminella et al. (19), Pandit et al. (27), and Del Pizzo et al. (28) reported the sensibility disorders evaluation (sensation or sensory loss) using VDS-3 $(6,12,27,28)$ or VAS-10 cm $(19)$, whereas Zucchelli et al. (31) reported the stress associated with the level of apprehension and fear experienced for the patient of jeopardizing the palatal wound. The aforementioned outcome measurements have been referred for FGG or CTG procedures. Finally, Ozcelik et al. (38) reported the impact of the patient's quality of life using the Oral Health Impact Profile-14 (OHIP-14), whereas the two investigations of Tavelli et al. $(36,37)$ focused on additional questions about the use of more painkillers after the surgery and his/her wish for repeat the palatal harvesting procedure if necessary. These two outcome measurements were reported for FGG procedure.

\section{Discussion}

Free gingival graft and CTG are two effective harvesting techniques performed on the palatal mucosa for periodontal and peri-implant plastic surgeries. Both techniques might be criticized due to patient morbidity. Therefore, it is of utmost importance that post-operative outcomes are included both in research reports as well as are assessed in clinical practice. Several methods to accelerate the healing process and to reduce postoperative pain and bleeding have been reported, but have not been organized as outcome measurements evaluated on clinical trials. The present study collects information about these outcomes in order to fill the lack of information. In the present review, the methods for outcome measurement evaluation following FGG or CTG procedures have been addressed. The modified EHI and the modified Landry WHI are two important indexes frequent- 
Table 2: Description of outcome definitions and measures related to postoperative patient-reported morbidity retrieved in the literature.

\begin{tabular}{|c|c|c|c|}
\hline Outcome & Measures & $\begin{array}{c}\text { Gingival } \\
\text { graft }\end{array}$ & Parameters \\
\hline $\begin{array}{l}\text { Pain perception }(6- \\
12,14,15,17,18,20,21,24- \\
30,35-37)\end{array}$ & $\begin{array}{c}\text { - Visual Analogue Scale (VAS 0-10 } \\
\text { cm) }(6,8-12,14,15,17,18,20,21,24- \\
\text { 27,29,30,35-37) } \\
\text { - Five-point Verbal Rating Scale } \\
\text { (VRS-5) }(7,27) \\
\text { - 101-point Numerical Rating Scale } \\
\text { (NSR-101) (10) } \\
\text { - Three-point Verbal Descriptor Scale } \\
\text { (VDS-3) (28) }\end{array}$ & FGG/CTG & $\begin{array}{c}\text { - 0: No; 10: Severe, extreme, } \\
\text { worst or unbearable pain }(8- \\
\text { 10,12,15,17,18,20,21,24,26,27,29,30,35- } \\
37) \\
\text { - 0: No; 1: Minimal; 10: Severe pain } \\
\quad(6,11,14) \\
\text { - No, mild, moderate, severe, very } \\
\text { severe pain }(7,27) \\
\text { - 0: No; 1: Minimal; 5: Moderate; } 10 \text { : } \\
\text { Severe pain }(25) \\
\text { - None, mild/moderate, severe pain }(28)\end{array}$ \\
\hline $\begin{array}{l}\text { Analgesic consumption } \\
(6,14,19-21,24,25,31,36,38)\end{array}$ & Number of analgesic consumptions & FGG/CTG & - Hours, days, weeks \\
\hline $\begin{array}{l}\text { Discomfort sensation } \\
(9,10,14,19,24,31,38)\end{array}$ & $\begin{array}{c}\text { - Visual Analogue Scale (VAS 0-10 } \\
\text { cm) }(9,14,19,24,31,38) \\
\text { - Four-point verbal rating scale } \\
\text { (VRS-4) }(10)\end{array}$ & FGG/CTG & $\begin{array}{l}\text { - 0: No discomfort; } 10 \text { : Extreme dis- } \\
\text { comfort }(9,14,24,31,38) \\
\text { - No discomfort, some discomfort, } \\
\text { considerable discomfort, discomfort } \\
\text { that could be more severe }(10)\end{array}$ \\
\hline $\begin{array}{l}\text { Burning sensation } \\
(14,18,20,24,26,29)\end{array}$ & $\begin{array}{l}\text { Visual Analogue Scale (VAS 0-10 } \\
\mathrm{cm})\end{array}$ & FGG/CTG & $\begin{array}{l}\text { - } 0 \text { : No burning sensation; } 10 \text { : Severe } \\
\text { burning sensation }(14,18,20,24,26,29)\end{array}$ \\
\hline $\begin{array}{l}\text { Changes in feeling habits } \\
(12,14,19,24,28,31)\end{array}$ & $\begin{array}{l}\text { - Change in quality (liquid, soft or } \\
\text { hard) and temperature of the food } \\
\text { (cold, tepid or warm) }(12,28) \\
\text { - Visual Analogue Scale (VAS 0-10 } \\
\text { cm) }(14,19,24) \\
\text { - Inability to chew (31) }\end{array}$ & FGG/CTG & $\begin{array}{l}\text { - Hard/warm: Normal; Liquid/cool: } \\
\text { Abnormal }(12,28) \\
\text { - 0: No changes; 10: Changes }(14,19,24) \\
\text { - Yes, no (31) }\end{array}$ \\
\hline $\begin{array}{l}\text { Sensibility disorders/sen- } \\
\text { sation loss }(6,12,19,27,28)\end{array}$ & $\begin{array}{l}\text { - Three-point Verbal Descriptor Scale } \\
\text { (VDS-3) }(6,12,27,28) \\
\text { - Visual Analogue Scale (VAS 0-10 } \\
\text { cm) (19) }\end{array}$ & FGG/CTG & $\begin{array}{l}\text { - None, moderate/mild, severe } \\
(6,12,27,28) \\
\text { - 0: No sensibility; 10: Sensibility (19) }\end{array}$ \\
\hline Stress (31) & $\begin{array}{l}\text { Level of apprehension and fear ex- } \\
\text { perience of jeopardizing the palatal } \\
\text { wound (VAS } 0-10 \mathrm{~cm})\end{array}$ & FGG/CTG & - 0: No stress; 10: Stress (31) \\
\hline Quality of Life (QoL) (38) & OHIP-14 & FGG & $\begin{array}{c}\text { - 0: Never; 1: Seldom; 2: Sometimes; } 3 \text { : } \\
\text { Fairly often; 4: Very often; 5: All time } \\
(38)\end{array}$ \\
\hline $\begin{array}{l}\text { Additional questions } \\
(36,37)\end{array}$ & $\begin{array}{l}\text { ¿Did you take any more painkillers } \\
\text { due to palatal pain since the } \\
\text { procedure was complete? } \\
\text { ¿If necessary, would you repeat the } \\
\text { palatal harvesting procedure? }\end{array}$ & FGG & - Yes, No $(36,37)$ \\
\hline
\end{tabular}

CTG: Connective Tissue Graft. FGG: Free Gingival Graft. OHIP-14: Oral Health Impact Profile-14.

ly used for evaluating the palatal wound healing after FGG or CTG harvesting. The hydrogen peroxide test is commonly used as a wound epithelialization test due to practicality and does not produce color stain on the superficial tissues as it occurs when the toluidine blue test is used. In addition, clinically, professionals could make objective evaluations based on tissue color match, consistency or swelling as well as healing areas and healing percentages considering proposed formulas. Wound epithelialization evaluated by means of photographs is considered a subjective method using visual inspection or wound healing areas performed using analysis programs. It would be interesting for consecutive evaluations, minimizing memory bias. Bleeding evaluation is an important method used immediate after the procedure and in postoperative controls, specially at early follow-ups. The cytological, laboratories and histological analyses were very little reported but are important 
methods for healing evaluation after FGG procedure, especially in research.

Patient-centered outcome measurements are also very important and represent a true outcome in clinical practice and research. It is important to highlight that pain perception, discomfort sensation, burning sensation, changes in feeding habits, sensibility disorders, and stress evaluation require numerical or verbal rating scales such as VAS-10 cm, VDS-3, VRS-5, NRS-101 or VRS-4 to register patient experience after FGG or CTG procedures. Although several numerical and verbal scales are currently used to assess pain intensity, it remains unclear which provides the most replicable, precise, and predictive valid measurement. Jensen et al. (39) compared the measurement of clinical pain intensity using VAS, NRS101, 11-point Box Scale (BS-11), 6-point Behavioral Rating Scale (BRS-6), VRS-4, and VRS-5. These authors concluded that all these scales showed predictive validity, thus were recommended for clinical use.

Several clinical trials reported different primary outcomes related to palatal wound healing after FGG procedure considering epithelialization $(7,9,19,21)$, clinical healing $(9,21)$, and remaining palatal wound area evaluation (24). Meanwhile, postoperative pain and discomfort sensation $(7,9,19,24)$, alteration of sensitivity, changes in feeling habits, consumption of analgesics $(19,24)$, and burning sensation $(21,24)$, have been reported as secondary outcomes. On the other hand, Ehab et al. (25) and Tavelli et al. (36) considered the postoperative pain perception as a primary outcome, whereas the re-epithelialization $(25,36)$, postsurgical bleeding, the analgesic consumption (25) and the question about willingness to repeat the treatment have been considered as secondary outcomes (36). In addition, Shanmugan et al. (26) considered the consistency and the color match such as objective outcomes, whereas the pain and the burning sensation were considered as subjective outcomes. Based on these findings, it may be argued that the methods related to the palatal wound healing evaluation are reported in clinical trials and could be considered as primary outcomes evaluated after FGG or CTG procedures. Considering the other group of variables described in the present review, Zucchelli et al. (31) included postoperative pain, discomfort sensation, bleeding, stress, and inability to chew as outcomes evaluated for patient morbidity. In this regard, Isler et al. (24) considered postoperative pain, discomfort sensation, changes in feeling habits, and burning sensation.

In the present review, several clinical trials evaluated the effect of platelet concentrates such as platelet-rich fibrin $(8,10,12,15,19)$, advanced platelet-rich fibrin (9), and titanium-platelet rich fibrin (20) on the palatal wound healing and patient morbidity. Interestingly, all these clinical trials demonstrated promising results facilitating wound healing and reducing postoperative morbidity and discomfort.
Although different outcome measurements have been described in the present review, the methods used for outcome evaluation following FGG or CTG harvesting are focused considering a combination of palatal wound healing evaluation and patient morbidity evaluation. In this review, the use of the grouped outcomes is recommended for clinicians that perform periodontal and peri-implant plastic surgeries in order to adequately control the postoperative conditions of the patients. Future research about palatal healing using periodontal dressings could analyze the effect. In addition, following this type of review, additional studies could focus on methods for outcome variable evaluation after third molar extraction. Moreover, it is clear from a research perspective, that trials should evaluate adverse events in clinical trials and also patient-centered outcomes. This is a recommendation of the CONSORT statement (40). Also, a considerable part of the evidence provided in clinical trials relates to decrease in morbidity and increase in patient satisfaction. This should be also part of clinical practice and the information coming from the present review adds possibilities of evaluation by clinicians.

\section{Conclusions}

The most commonly used outcome measurements related to postoperative palatal wound healing are hydrogen peroxide test, tissue color match, visual inspection, and bleeding evaluation. In addition, pain perception, analgesic consumption, discomfort sensation, burning sensation, and changes in feeling habits are the most commonly used outcome measurements related to postoperative patient-reported morbidity. These outcome measurements should be part of clinical evaluation in the field.

\section{References}

1. Zuhr O, Bäumer D, Hürzeler M. The addition of soft tissue replacement grafts in plastic periodontal and implant surgery: critical elements in design and execution. J Clin Periodontol. 2014;41:123-42. 2. Zucchelli G, Tavelli L, McGuire MK, Rasperini G, Feinberg SE, Wang HL, et al. Autogenous soft tissue grafting for periodontal and peri-implant plastic surgical reconstruction. J Periodontol. 2020;91:9-16. 3. Tavelli L, Barootchi S, Revidà A, Oh TJ, Wang HL. What is the safety zone for palatal soft tissue graft harvesting based on the locations of the greater palatine artery and foramen? A Systematic Review. J Oral Maxillofac Surg. 2019;77:1-9.

4. Sanz M, Simion M, Working Group 3 of the European Workshop on Periodontology. Surgical techniques on periodontal plastic surgery and soft tissue regeneration: consensus report of Group 3 of the 10th European Workshop on Periodontology. J Clin Periodontol. 2014;41:92-7. 5 . Farnoush A. Techniques for the protection and coverage of the donor sites in free soft tissue grafts. J Periodontol. 1978;49:403-5.

6. Keceli HG, Aylikci BU, Koseoglu S, Dolgun A. Evaluation of palatal donor site haemostasis and wound healing after free gingival graft surgery. J Clin Periodontol. 2015;42:582-9.

7. Sharma V, Kumar A, Puri K, Bansal M, Khatri M. Application of platelet-rich fibrin membrane and collagen dressing as palatal bandage for wound healing: A randomized clinical control trial. Indian J Dent Res. 2019;30:881-8.

8. Patarapongsanti A, Bandhaya P, Sirinirund B, Khongkhunthian S, Khongkhunthian P. Comparison of platelet-rich fibrin and cellulose in 
palatal wounds after graft harvesting. J Investig Clin Dent. 2019;10:1 7.

9. Sousa F, Machado V, Botelho J, Proença L, Mendes JJ, Alves R. Effect of A-PRF application on palatal wound healing after free gingival graft harvesting: A prospective randomized study. Eur J Dent. 2020;14:63-9.

10. Bahammam MA. Effect of platelet-rich fibrin palatal bandage on pain scores and wound healing after free gingival graft: a randomized controlled clinical trial. Clin Oral Investig. 2018;22:3179-88.

11. Fickl S, Fischer KR, Jockel-Schneider Y, Stappert CF, Schlagenhauf U, Kebschull M. Early wound healing and patient morbidity after single-incision vs. trap-door graft harvesting from the palate--a clinical study. Clin Oral Investig. 2014;18:2213-9.

12. Ozcan M, Ucak O, Alkaya B, Keceli S, Seydaoglu G, Haytac MC. Effects of platelet-rich fibrin on palatal wound healing after free gingival graft harvesting: A comparative randomized controlled clinical trial. Int J Periodontics Restorative Dent. 2017;37:270-8.

13. Moher D, Liberati A, Tetzlaff J, Altman DG. Preferred reporting items for systematic reviews and meta-analyses: the PRISMA statement. BMJ. 2009;339:b2535.

14. Isler SC, Eraydin N, Akkale H, Ozdemir B. Oral flurbiprofen spray for mucosal graft harvesting at the palatal area: A randomized placeb-controlled study. J Periodontol. 2018;89:1174-83.

15. Lektemur Alpan A, Torumtay Cin G. PRF improves wound healing and postoperative discomfort after harvesting subepithelial connective tissue graft from palate: A randomized controlled trial. Clin Oral Investig. 2020;24:425-36.

16. Wachtel H, Schenk G, Böhm S, Weng D, Zuhr O, Hürzeler MB. Microsurgical access flap and enamel matrix derivative for the treatment of periodontal intrabony defects: A controlled clinical study. J Clin Periodontol. 2003;30:496-504.

17. Samani MK, Saberi BV, Ali Tabatabaei SM, Moghadam MG. The clinical evaluation of platelet-rich plasma on free gingival graft's donor site wound healing. Eur J Dent. 2017;11:447-54.

18. Ustaoglu G, Ercan E, Tunali M. Low-level laser therapy in enhancing wound healing and preserving tissue thickness at free gingiva graft donor sites: A randomized, controlled clinical study. Photomed Laser Surg. 2017;35:223-30.

19. Femminella B, Iaconi MC, Di Tullio M, Romano L, Sinjari B, D'Arcangelo C, et al. Clinical comparison of platelet-rich fibrin and a gelatin sponge in the management of palatal wounds after epithelialized free gingival graft harvest: A randomized clinical trial. J Periodontol. 2016;87:103-13.

20. Ustaoğlu G, Ercan E, Tunali M. The role of titanium-prepared platelet-rich fibrin in palatal mucosal wound healing and histoconduction. Acta Odontol Scand. 2016;74:558-64.

21. Heidari M, Paknejad M, Jamali R, Nokhbatolfoghahaei H, Fekrazad R, Moslemi N. Effect of laser photobiomodulation on wound healing and postoperative pain following free gingival graft: A split-mouth triple-blind randomized controlled clinical trial. J Photochem Photobiol B. 2017;172:109-14.

22. Soheilifar S, Bidgoli M, Hooshyarfard A, Shahbazi A, Vahdatina F, Khoshkhooie F. Effect of oral bromelain on wound healing, pain, and bleeding at donor site following free gingival grafting: A clinical trial. J Dent (Tehan): 2018;15:309-16.

23. Yaghobee S, Rouzmeh N, Aslroosta H, Mahmoodi S, Khorsand A, Kharrazifard MJ. Effect of topical erythropoietin (EPO) on palatal wound healing subsequent to free gingival grafting (FGG). Braz Oral Res. 2018;32:1-10.

24. Isler SC, Uraz A, Guler B, Ozdemir Y, Cula S, Cetiner D. Effects of Laser photobiomodulation and ozone therapy on palatal epithelial wound healing and patient morbidity. Photomed Laser Surg. 2018;36:571-80.

25. Ehab K, Abouldahab O, Hassan A, Fawzy El-Sayed KM. Alvogyl and absorbable gelatin sponge as palatal wound dressings following epithelialized free gingival graft harvest: a randomized clinical trial. Clin Oral Investig. 2020;24:1517-25.

26. Shanmugam M, Kumar TS, Arun KV, Arun R, Karthik SJ. Clinical and histological evaluation of two dressing materials in the healing of palatal wounds. J Indian Soc Periodontol. 2010;14:241-4.

27. Pandit N, Khasa M, Gugnani S, Malik R, Bali D. Comparison of two techniques of harvesting connective tissue and its effects on healing pattern at palate and recession coverage at recipient site. Contem Clin Dent. 2016;7:3-10.

28. Del Pizzo M, Modica F, Bethaz N, Priotto P, Romagnoli R. The connective tissue graft: a comparative clinical evaluation of wound healing at the palatal donor site. A preliminary study. J Clin Periodontol. 2002;29:848-54.

29. Yıldırım S, Özener HÖ, Doğan B, Kuru B. Effect of topically applied hyaluronic acid on pain and palatal epithelial wound healing: An examiner-masked, randomized, controlled clinical trial. J Periodontol. 2018;89:36-45.

30. da Silva Neves FL, Silveira CA, Dias SB, Júnior MS, Carvalho de Marco A, Kerbauy WD, et al. Comparison of two power densities on the healing of palatal wounds after connective tissue graft removal: randomized clinical trial. Laser Med Sci. 2016;31:1371-8.

31. Zucchelli G, Mele M, Stefanini M, Mezzotti C, Marzadori M, Montebugnoli L, et al. Patient morbidity and root coverage outcome after subepithelial connective tissue and de-epithelialized grafts: a comparative randomized-controlled clinical trial. J Clin Periodontol. 2010;37:728-38.

32. Patel PV, Kumar V, Kumar S, Gd V, Patel A. Therapeutic effect of topical ozonated oil on the epithelial healing of palatal wound sites: a planimetrical and cytological study. J Investig Clin Dent. 2011;2:24858.

33. Patel PV, Kumar S, Vidya GD, Patel A, Holmes JC, Kumar V. Cytological assessment of healing palatal donor site wounds and grafted gingival wounds after application of ozonated oil: an eighteen-month randomized controlled clinical trial. Acta Cytol. 2012;56:277-84.

34. Keskiner I, Lutfioğlu M, Aydogdu A, Saygun NI, Serdar MA. Effect of photobiomodulation on transforming growth factor- $\beta 1$, platelet-derived growth factor-BB, and interleukin-8 release in palatal wounds after free gingival graft harvesting: A randomized clinical study. Photomed Laser Surg. 2016;34:263-71.

35. Dias SB, Fonseca MV, Dos Santos NC, Fernandes I, Marthino FC, Santamaria M, et al. Effect of GaAIAs low-level laser therapy on the healing of human palate mucosa after connective tissue graft harvesting: randomized clinical trial. Lasers Med Sci. 2015;30:1695-1702.

36. Tavelli L, Asa'ad F, Acunzo R, Pagni G, Consonni D, Rasperini G. Minimizing patient morbidity following palatal gingival harvesting: A randomized controlled clinical study. Int J Periodontics Restorative Dent. 2018:38:127-34.

37. Tavelli L, Ravidà A, Saleh MHA, Maska B, Suárez-López del Amo F, Rasperirni G, et al. Pain perception following epithelialized gingival graft harvesting: A randomized clinical trial. Clin Oral Investig. 2019;23:459-68.

38. Ozcelik O, Seydaoglu G, Haytac CM. Diode laser for harvesting de-epithelialized palatal graft in the treatment of gingival recession defects: A randomized clinical trial. J Clin Periodontol. 2016;43:63-71. 39. Jensen MP, Karoly P, Braver S. The measurement of clinical pain intensity: a comparison of six methods. Pain. 1986;27:117-26.

40. Moher D, Hopewell S, Schulz KF, Montori V, Gotzsche PC, Devereaux PJ, et al. CONSORT 2010 explanation and elaboration: Updated guidelines for reporting parallel group randomised trials. BMJ. 2010;340:C869.

\section{Source of funding}

The authors declare no source of funding for this review.

\section{Authors' contributions}

- 1 and 2: They have made substantial contributions to conceptualization, acquisition of data, analysis and interpretation of data. Original draft preparation and writing, review and editing.

- 3 and 4: They have been involved in conceptualization and drafting of the manuscript. Original draft preparation and writing.

- 5 and 6: They have made substantial contributions in conceptualization, draft preparation and writing, review and editing. 
All authors declare that they contributed to critical review of intellectual content and approval of the final version to be published.

\section{Conflict of interest}

The authors declare no conflicts of interest pertaining to the preparation of this review. 